\title{
The effect of Lactobacillus plantarum hydrolysates promoting VEGF production on vascular growth and hair growth of C57BL/6 mice
}

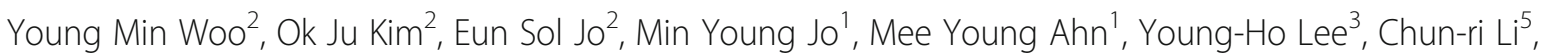 \\ Sang-Hyeon Lee ${ }^{1}$, Jae-Suk Choi ${ }^{4}$, Jong Myung Ha ${ }^{1}$ and Andre Kim ${ }^{1 *}$ D
}

\begin{abstract}
Purpose: Angiogenesis is critical in various biological processes, such as blood vessel growth, fetal differentiation, wound healing, and organ regeneration. Various growth factors have been associated with vascular regeneration, including insulin-like growth factor 1 (IGF-1), transforming growth factor- $\beta$ (TGF- $\beta$ ), and basic fibroblast growth factor (bFGF). One of the most important mediators of vascular regeneration is vascular endothelial growth factor (VEGF). VEGF is known to increase vascular permeability, induce the proliferation of endothelial cells, and stimulate capillary formation in vivo, which are core angiogenic functions.
\end{abstract}

Methods: The hydrolysates of lactic acid bacteria were produced by hydrolyzing Lactobacillus plantarum with proteases, treated with MG-63 osteoblasts, and screened to obtain samples with an excellent VEGF production effect. These samples were applied to human dermal papilla cells (hDPC) to examine the correlation between cell growth and VEGF secretion. Furthermore, the hair growth rate was measured in hair growth experiments using C57BL/6 male mice.

Results: The hydrolysates of the lactic acid bacteria produced in this study produced hair growth superior to the growth obtained with 5\% minoxidil in hair growth experiments using C57BL/6 male mice.

Conclusions: This study aims to develop a material for application to the scalp that promotes angiogenesis in the scalp and facilitates the exchange of nutrients and wastes in the follicles to promote hair growth.

Keywords: Vascular endothelial growth factor (VEGF), Lactobacillus plantarum, Protease, Human dermal papilla cell (hDPC), Hair growth

\section{Background}

Hair loss treatments applied directly to the scalp that are currently researched include helping hair growth by nutrient supply and the release of harmful elements through vasodilation or blood circulation promotion, reducing stress on the hair follicle by inhibiting the generation of reactive oxygen species (ROS) or nitric oxide (NO) that cause inflammation, reducing the risk factors

\footnotetext{
* Correspondence: adrk@silla.ac.kr

${ }^{1}$ Major in Pharmaceutical Engineering, Division of Bioindustry, College of Medical and Life Sciences, Silla University, 140 Baegyang-daero(Blvd),

700beon-gil(Rd.), Sasang-Gu, Busan 46958, South Korea

Full list of author information is available at the end of the article
}

of follicles by inhibiting the formation of cytokines, and strengthening the hair follicles by promoting angiogenesis (Hibino et al. 2004). Angiogenesis is a critical factor in various biological processes such as blood vessel growth, fetal differentiation, wound healing, and organ regeneration. Various growth factors have been associated with vascular regeneration, including tumor necrosis factor (TNF), transforming growth factor- $\beta$ (TGF- $\beta$ ), and basic fibroblast growth factor (bFGF) (Suh et al. 2005). The formation of new blood vessels from existing capillaries is accomplished by a combination of angiogenic factors, extracellular matrix, and protease. 
One of the most important mediators of vascular regeneration is vascular endothelial growth factor (VEGF). VEGF is known to increase vascular permeability, induce the proliferation of endothelial cells, and stimulate capillary formation in vivo, which are core angiogenic functions (Miele et al. 2000; Yeh et al. 1999). VEGF has been reported to induce alkaline phosphatase activity and enhance the response to parathyroid hormone in osteoblasts such as MG-63. Osteoblasts show the highest affinity for VEGF receptors, suggesting that many functional VEGF receptors are present in osteoblasts (Goad et al. 1996).

In particular, there are also reports that VEGF is secreted in dermal papilla cells. In light of the fact that there are rich capillaries in the papilla during hair growth, but that they disappear during the transition into the resting period, it is thought that the growth of blood vessels is associated with hair growth and thus that VEGF is involved in hair growth. VEGF has been also reported to reduce hair loss by promoting blood circulation and the formation of new blood vessels around follicles (Back et al. 1999).

The growth factors secreted from dermal papilla cells include basic fibroblast growth factor, insulin-like growth factor-1 (IGF-1), hepatocyte growth factor (HGF), fibroblast growth factor 1 (FGF1), and keratinocyte growth factor (KGF) (Kwon et al. 2007; Philpott et al. 1994; Mitsul et al. 1997). Transforming growth factor beta 2 (TGF $\beta 2$ ) has been found to be a key factor for inducing a regression period, as it is expressed in follicles when the hair transitions from the growth period into the regression period. In addition, TGF $\beta 2$ has been found to inhibit the proliferation of epithelial cells and shorten the human hair cycle (Park et al. 2016; Foitzik et al. 2005).

The representative drugs that stimulate hair growth are minoxidil and $5 \alpha$-reductase inhibitors such as finasteride and dutasteride. These drugs have been approved by the U.S. Food and Drug Administration (FDA). Minoxidil was originally developed as a vasodilator for the treatment of hypertension. Although its mechanism of action on hair growth has not been clearly revealed, it is thought that the increase of nutritional supply through vasodilation and the $\mathrm{K}^{+}$channel opening effect induce hair growth (Jamora et al. 2005; Buhl et al. 1990). Furthermore, minoxidil is considered to induce VEGF expression, promote the growth of cells, including follicular keratinocyte, that are used for hair growth, and improve blood circulation by stimulating vascular endothelial cells and smooth muscles, for minoxidil is also used for hypertension treatment (Messenger et al. 2004). Finasteride is a hair growth agent that prevents typical male hair loss by inhibiting the activity of $5 \alpha$-reductase, a reductase that converts testosterone to dihydrotestosterone (DHT), which has the effect of preventing the death of follicle cells by DHT. However, sustained drug use is required to maintain the hair growth-promoting effect of finasteride, and side effects, such as sexual dysfunction in men and birth defects in pregnant women, have been reported (Do et al. 2011; Olsen et al. 2002).

To minimize these side effects, much research has been conducted on therapeutic agents and treatments that use natural materials for hair growth, and they suggest the possibility of developing agents that produce excellent hair growth from natural materials (Hwang et al. 2017; Hyung et al. 2007; Shapiro et al. 1998). Currently, clinical trials are being conducted on the hair growth-promoting effect of compounds using the root extracts of Rosa multiflora as a main component. Furthermore, the effects on hair growth of hair tonic, food containing medicinal herbs, algae extracts, and black bean extracts are being researched (Kim 2014; Choi et al. 2011; Ha et al. 2013; Jeon et al. 2011).

The Lactobacillus plantarum used in these experiments is widely used as a probiotic, and these lactic acid bacteria can be easily found not only in nature, but also in fermented foods and animal intestines (Chang et al. 2010; Choi et al. 2015). L. plantarum is used for antimicrobial activity, ACE (angiotensin-converting enzyme) inhibition, lipid metabolism, and hair growth (Axling et al. 2012; Joo 2011; Lee et al. 2012). It is also used as an individually acknowledged raw material for health foods that are commercialized as lactic acid bacteria products for skin health (Choi et al. 2013; Kang et al. 2009). Therefore, in this study, the effects on hair growth of $L$. plantarum proteins hydrolyzed using various proteases were analyzed in vitro and in vivo.

\section{Results and discussion \\ Results}

Cytotoxicity test after treatment of Lactobacillus plantarum hydrolysates

The $L$. plantarum enzyme hydrolysates were treated with MG-63 cells and human dermal papilla cells (hDPC) at concentrations of $0,31.25,62.5,125,250$, and $500 \mu \mathrm{g} / \mathrm{mL}$. They were cultured for $24 \mathrm{~h}$ and analyzed by CCK assay. The results are shown in Fig. 1. In the MG-63 cells (Fig. 1a), there were no significant differences between the control group and all groups except the Lactobacillus plantarum by Protamex (LP-P) group for concentrations of 0 up to $250 \mu \mathrm{g} / \mathrm{mL}$. In the hDPC (Fig. 1b), the cells did not show toxicity for concentrations of 0 up to $250 \mu \mathrm{g} / \mathrm{ml}$. Thus, cell growth experiments were carried out at a concentration of $200 \mu \mathrm{g} / \mathrm{mL}$, which is the highest concentration that does not exhibit toxicity.

\section{Measurement of growth rate after treatment with Lactobacillus plantarum hydrolysates}

To determine the growth rates of MG-63 cells and $\mathrm{hDPC}$, cell growth was measured for 10 days. The results 

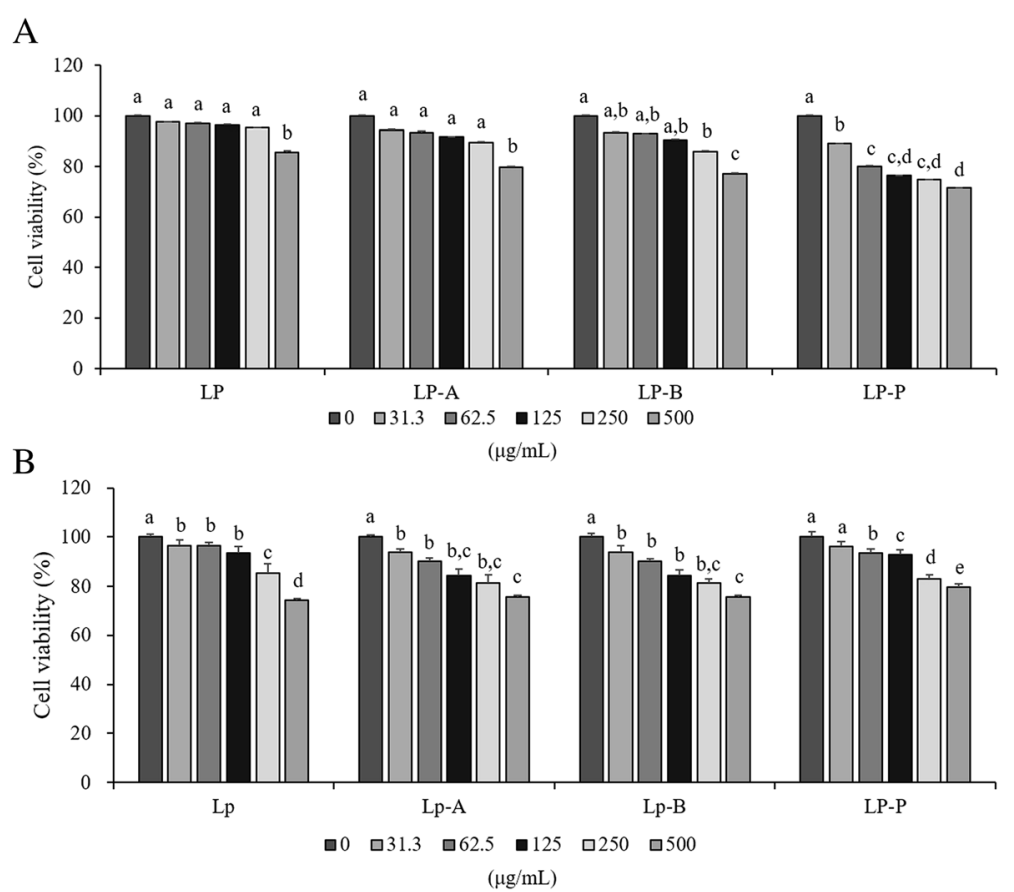

Fig. 1 Determination of the viability of a MG-63 cell and $\mathbf{b}$ hDPC ( $24 \mathrm{~h})$. The values are the means \pm SD of three independent experiments, and the cell proliferation effect on the hydrolysates was represented as a percentage. The letters a, b, $c$, $d$, and e above the bars stand for significantly different $(p<0.05)$ groups by one-way ANOVA, followed by Duncan's multiple test. Cell viability was determined by CCK assay. *Values are the means \pm SD of three independent experiments $(n=3)$

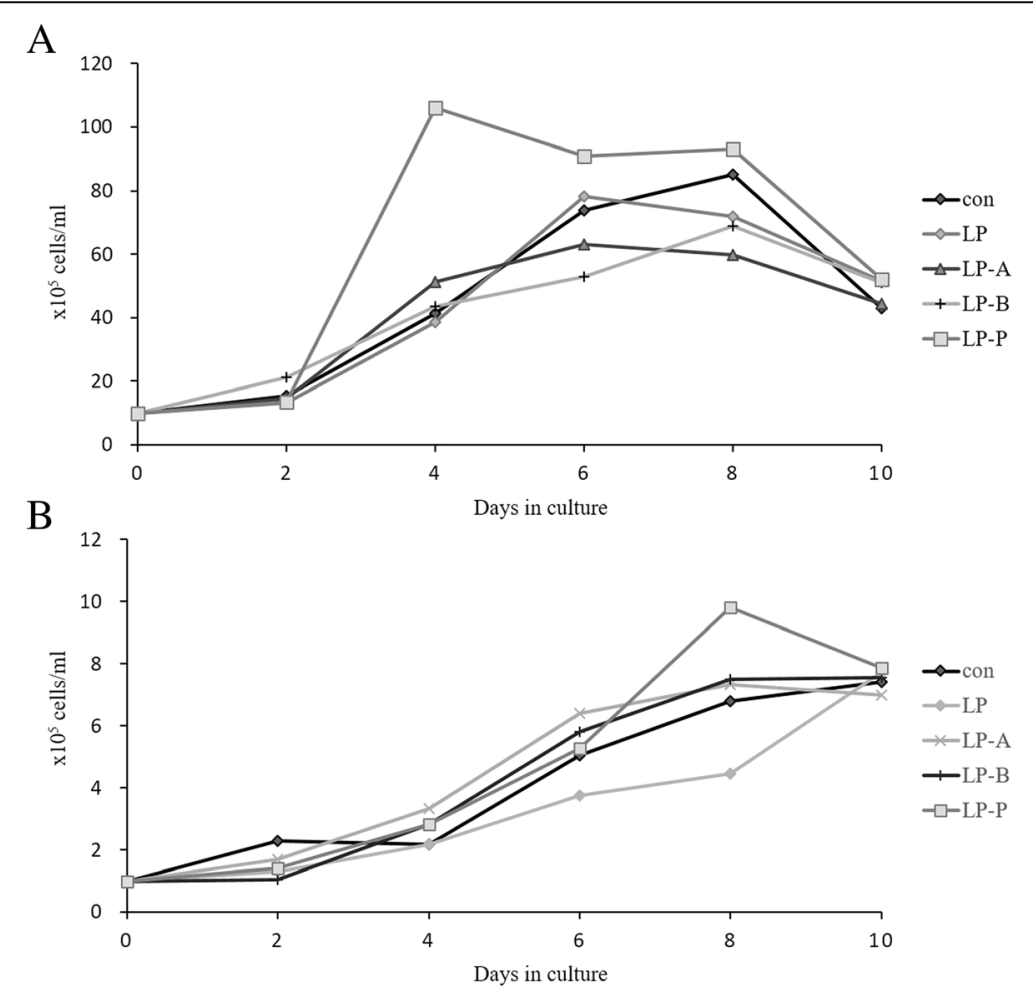

Fig. 2 Growth of a MG-63 cells and $\mathbf{b}$ hDPC over 10 days. The control (con) group was not a treated sample, hydrolysates of L. plantarum (LP), hydrolysates of $L$. plantarum by Alcalase ( $L P-A)$, hydrolysates of $L$. plantarum by bromelain $(L P-B)$, and hydrolysates of $L$. plantarum by Protamex $(L P-P)$ 
are shown in Fig. 2. The L. plantarum enzyme hydrolysates were treated at a concentration of $200 \mu \mathrm{g} / \mathrm{mL}$ in the medium. MG-63 cells showed steady growth until the eighth day of growth, but the cell growth decreased after the eighth day. The growth rate of the LP-P group (see Fig. 1a) was lower than that of the other groups both up until, and after, $24 \mathrm{~h}$ of CCK assay. As shown in Fig. 2a, the LP, Lactobacillus plantarum by Alcalase (LP-A), and Lactobacillus plantarum by bromelain (LP-B) groups showed similar growth cycles to those of the control group, whereas LP-P showed rapid growth of $106.0 \times 10^{5}$ cells $/ \mathrm{mL}$ at day 4 after culture, $91.0 \times 10^{5}$ cells at day 6 , and $93.3 \times 10^{5}$ cells $/ \mathrm{mL}$ at day 8 .

The growth of hDPC was measured for 10 days and the results are shown in Fig. 2b. The samples showed steady growth for 10 days. The LP-P group in particular showed rapid growth on the eighth day. This result is the same as that of the MG-63 cells. The LP-P group showed the rapid growth of $5.28 \times 10^{5}$ cells $/ \mathrm{mL}$ at day 6 of culture and $7.51 \times 10^{5}$ cells $/ \mathrm{mL}$ at day 8 .

\section{Measurement of VEGF concentration}

The amounts of VEGF and IGF-1 secreted from the MG-63 and hDPC growth medium were measured by ELISA, and the results are shown in Fig. 3 (a, b). The concentration of the LP-B-treated group in the MG-63 cells was $3730.44 \mathrm{pg} / \mathrm{mL}$, which was $262.73 \%$ higher than that of the control group. The concentrations of LP-A and LP-P treatments were $2827.11 \mathrm{pg} / \mathrm{mL}$ and 2766.56 $\mathrm{pg} / \mathrm{mL}$, respectively, which were $199.11 \%$ and $194.84 \%$ higher than those of the control group, respectively. The results of VEGF measurement in the hDPC growth medium are shown in Fig. 3b. Similarly to the MG-63 cell concentrations, the VEGF concentrations in the LP-B group and the LP-P group were $148.58 \mathrm{pg} / \mathrm{mL}$ and $112.96 \mathrm{pg} / \mathrm{mL}$, respectively, which were $221.60 \%$ and $168.47 \%$ higher than those of the control group $(67.05$ $\mathrm{pg} / \mathrm{mL}$ ), respectively. Madaan et al. (2017) reported that minoxidil sulfate demonstrated stimulation of VEGF in DPCs. The VEGF concentrations in the minoxidil $(1 \mu \mathrm{M})$ were about $100 \mathrm{pg} / \mathrm{mL}$.

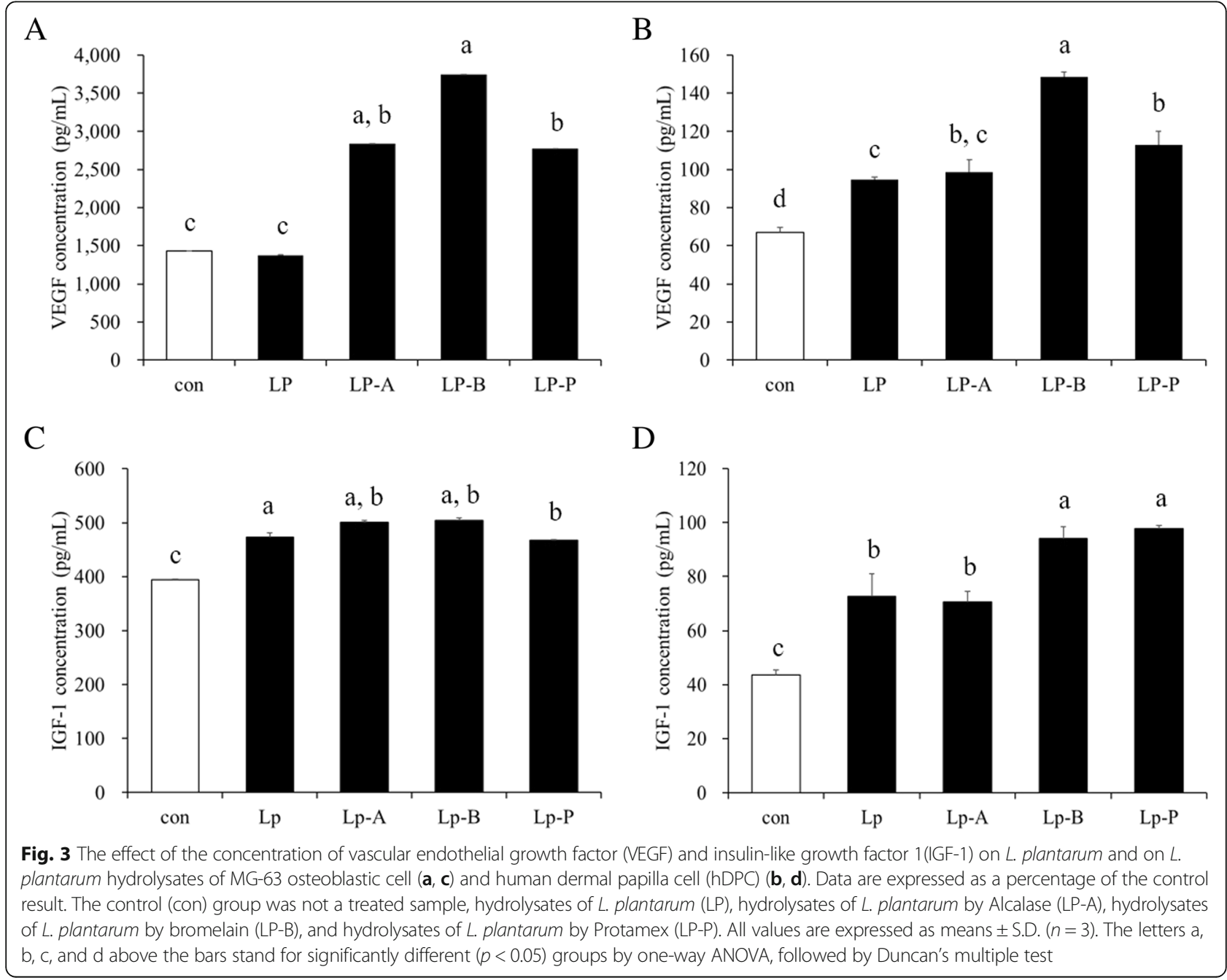




\section{Measurement of IGF-1 concentration}

The amount of IGF-1 secreted from the MG-63 growth medium was measured by ELISA, and the results are shown in Fig. 3 (c, d). The concentration of the LP-B-treated group in the MG-63 cells was $504.12 \mathrm{pg} /$ $\mathrm{mL}$, which was $128.04 \%$ higher than that of the control group. The concentrations of LP-A and LP-P treatments were $500.71 \mathrm{pg} / \mathrm{mL}$ and $467.82 \mathrm{pg} / \mathrm{mL}$, respectively, which were $127.18 \%$ and $118.82 \%$ higher than those of the control group, respectively. The results of IGF-1 measurement in the hDPC growth medium are shown in Fig. 3d. The IGF-1 concentrations in the LP-P group and the LP-B group were $97.82 \mathrm{pg} / \mathrm{mL}$ and $94.12 \mathrm{pg} / \mathrm{mL}$, respectively, which were $223.79 \%$ and $215.33 \%$ higher than those of the control group $(43.71 \mathrm{pg} / \mathrm{mL})$, respectively.

\section{Hair growth (appearance)}

After hair removal, the appearance of hair was visually observed and recorded (Figs. 4 and 5). On the first day of sample application, the skin color of the backs of all groups was scarlet, and the hair began to grow little by little from the seventh day of sample application. After 9 days, the entire skin that had been epilated was black, as the skin hair began to grow. On the 12th day after sample application, hair had grown in all groups, although there were differences among the groups. The LP-P group and the LP-B group had more hair than the control group. In particular, the LP-P group and the LP-B group showed the best hair growth.

\section{Hair growth (dorsal tissue)}

It has been shown that when hair starts growing, the skin turns gray or black. Based on this report, it was observed that the LP-P group and the minoxidil group, which are the experimental groups, had completely black medial dorsal skin color and dilated blood vessels (Fig. 6). Because the hair had almost all grown out according to the visual observation of its appearance, it was confirmed that the hair had partially entered the regression period. The con, LP, and LP-A groups showed partially light gray skin, but, on visual observation, the part where the hair did not grow was found not to be entering the growth period, as it was observed in the medial dorsal tissues.

\section{Discussion}

Cell growth and VEGF were measured to determine the effect of L. plantarum hydrolysates on the proliferation and activity of MG-63 osteoblast-like cells and hDPC. After L. plantarum was hydrolyzed with Protamex, MG-63 osteoblast-like cells showed a high growth rate of $257 \%$ on the fourth day of culture, compared to the control group. The group hydrolyzed with bromelain showed a growth rate of $105 \%$ compared to the control group. This is thought to be due to the hydrolyzed peptide of lactic acid bacteria. hDPC produced steady hair growth for 10 days. In particular, the LP-P group showed rapid hair growth on day 8 , and this result is the same as that of MG-63 cells.

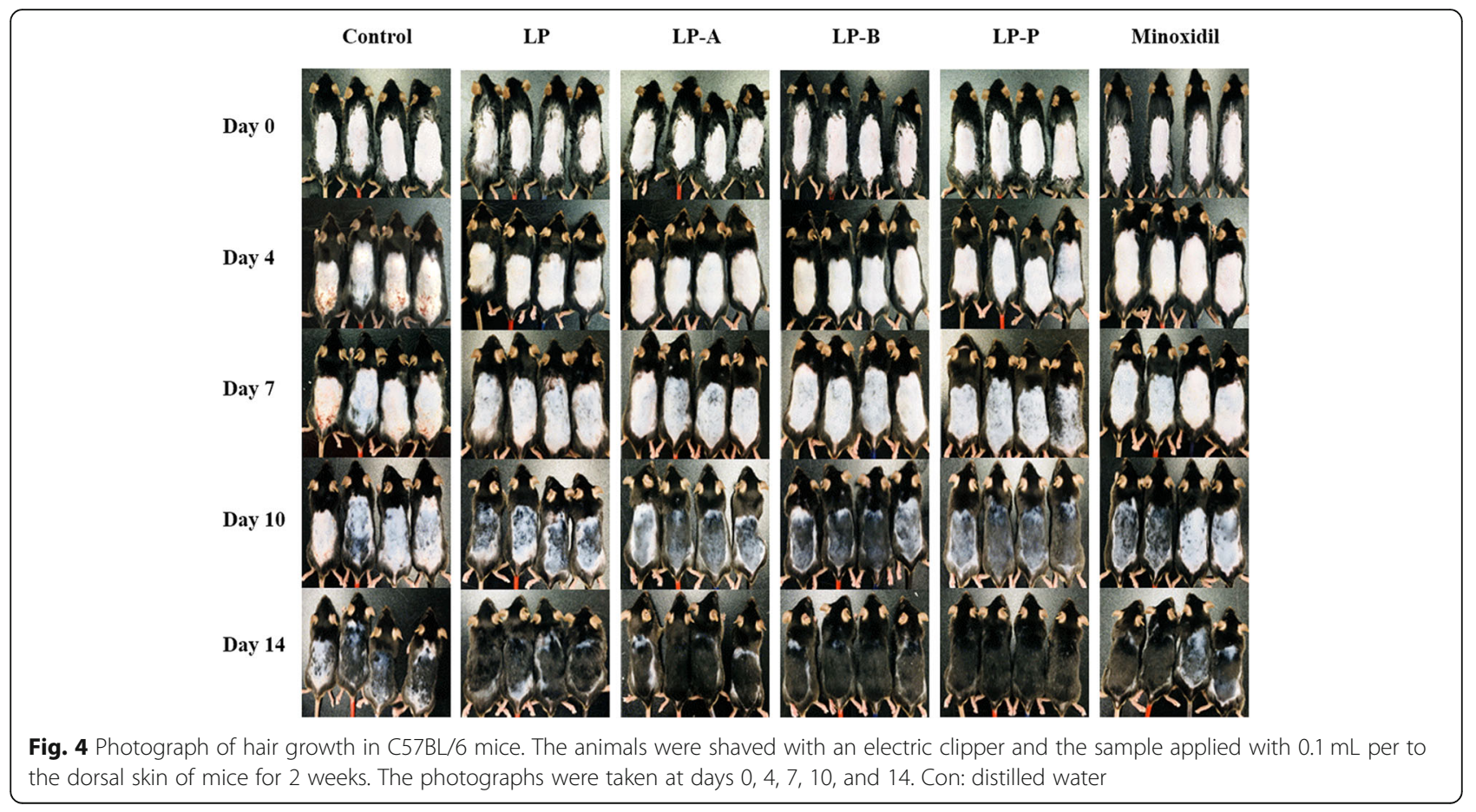




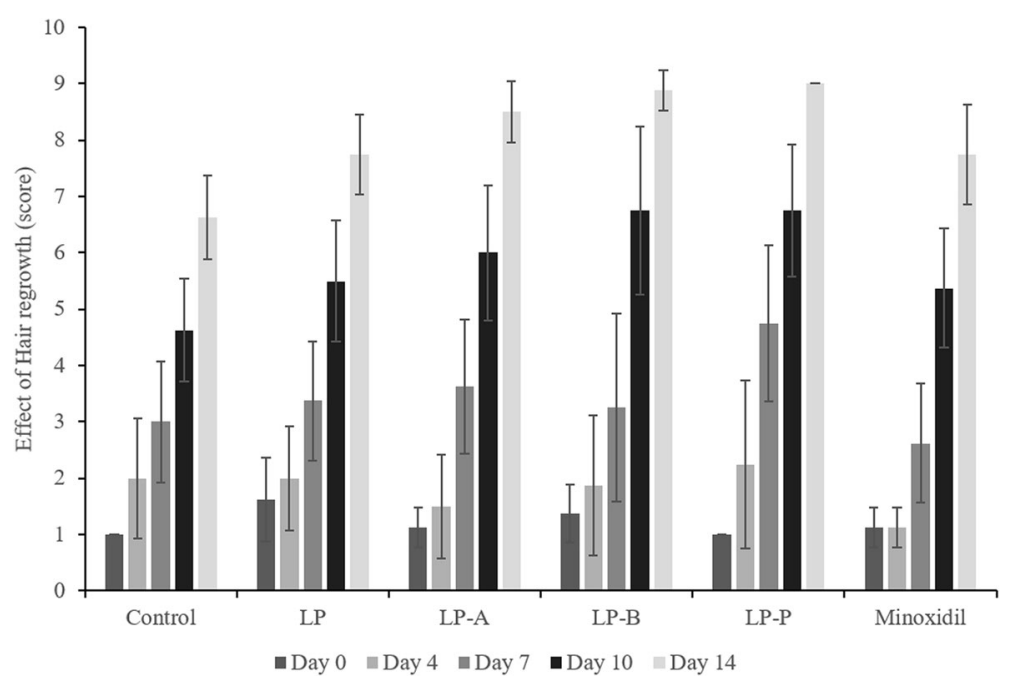

Fig. 5 Hair growth score. Hair regrowth was evaluated inspecting by the gray- or black-colored area (\%) on the reverse side of the skin

VEGF is a growth hormone that is closely correlated with cell growth because it is secreted during the growth of osteoblasts such as MG-63 to induce cell migration, survival, and proliferation. It has been also reported to reduce hair loss by forming new blood vessels and promoting blood circulation around the hair follicles (Deckers et al. 2000). For stem cell cultures used in cosmetics, the concentration of VEGF was found to be about $3500-4000 \mathrm{pg} / \mathrm{mL}$. The VEGF measured in the MG-63 cell media was $3730 \mathrm{pg} / \mathrm{mL}$ in bromelain hydrolysates and $2827 \mathrm{pg} / \mathrm{mL}$ in Protamex hydrolysates, which is higher by $262.73 \%$ and $199.11 \%$ than the figures for the control group $(1420 \mathrm{pg} / \mathrm{mL})$, respectively.

Cell growth was higher in the LP-P group than in the LP-B group, but the VEGF secretion rate was higher in the LP-B group. The VEGF secreted from the hDPC growth medium was measured as $149 \mathrm{pg} / \mathrm{mL}$ in the LP-B group and as $113 \mathrm{pg} / \mathrm{mL}$ in the LP-P group, which was $222 \%$ and $169 \%$ higher than the figures for the control group, respectively.

Hair growth was observed in the C57BL/6 mice. On the seventh day, the LP-P treatment group showed a skin color close to black, and hair growth was visually observed on the eighth day. In the LP-P, P-con, and LP-B groups, many blood vessels were observed to have expanded in the median dorsal skin tissues, and their skin color changed to black.

\section{Materials and methods}

Strain and medium used

Lactobacillus plantarum was purchased from KCCM (KCCM 11322, Korea Federation of Culture Collection, Seoul, Korea). MRS broth (Difco, Detroit, MI, USA) was used as the lactic acid bacteria culture medium and was anaerobically cultured at $37^{\circ} \mathrm{C}$ for $48 \mathrm{~h}$.

\section{Production of Lactobacillus plantarum protein enzyme hydrolysates}

The protease activity of $L$. plantarum, and Alcalase (Novozyme Co., Bagsvaerd, Denmark), bromelain (Novozyme), and Protamex (Novozyme), which are different types of protease, were reacted with the cultured L. plantarum by adjusting the active optimal temperature and $\mathrm{pH}$ (Alcalase, $50^{\circ} \mathrm{C}, \mathrm{pH} 7$; bromelain, $45^{\circ} \mathrm{C}, \mathrm{pH} 7$; Protamax, $\left.60^{\circ} \mathrm{C}, \mathrm{pH} 7\right)$. They were added to make a $1 \%$ protein concentration and hydrolyzed for $2 \mathrm{~h}$

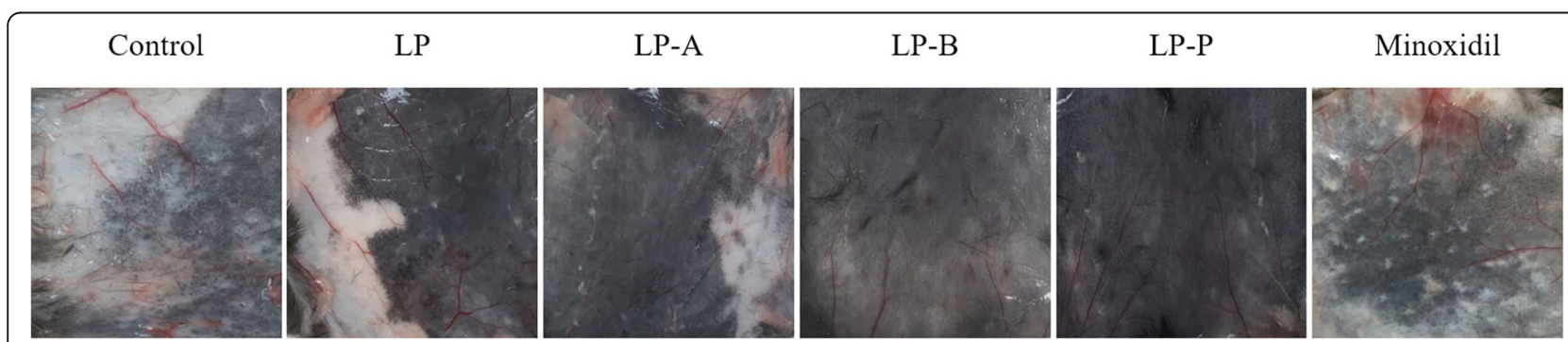

Fig. 6 Hair growth on the reverse side of the skin. After the gray skin color was detected, the skin was isolated and the reverse side was photographed to evaluate dilated blood vessels 
(LP-A: L. plantarum hydrolysates by Alcalase; LP-B: $L$. plantarum hydrolysates by bromelain; LP-P: L. plantarum hydrolysates by Protamex). The protein concentration was determined by drawing a standard curve using the Bradford method with bovine serum albumin (BSA) at $R^{2}=0.9951$ as a standard sample. These $L$. plantarum protein enzyme hydrolysates were freeze-dried and used as samples.

\section{Cell culture}

In this study, MG-63 osteoblast-like cells were used as controls for hDPC. The human osteoblast-like MG-63 cells used in this study were purchased from Korea Cell Line Bank (KCLB, Seoul, Korea), and the human dermal papilla cells (hDPC) were purchased from Cell Engineering for Origin (CEFO Co., Seoul, Korea). The cultured cells were subcultured in our laboratory. Ten percent FBS (Gibco, Grand Island, NY, USA) and 1\% antibacterial-antifungal solution were added to the DMEM (Gibco, Grand Island, NY, USA). During the culture, $5 \% \mathrm{CO}_{2}$ was continuously supplied while maintaining the temperature at $37^{\circ} \mathrm{C}$.

\section{Cell toxicity and cell growth rate after treatment of Lactobacillus plantarum protein enzyme hydrolysates}

A CCK assay was used to verify cytotoxicity. MG-63 cells and hDPC were dispensed at a concentration of $6 \times 10^{3}$ cells/well on a 96-well plate. After $24 \mathrm{~h}$, the $L$. plantarum protein enzyme hydrolysates were added at concentrations of $0,31.25,62.5,125,250$, and $500 \mu \mathrm{g} /$ $\mathrm{mL}$ and cultured for another $24 \mathrm{~h}$. After the culture, a CCK reagent (Dongin LS, Seoul, Korea) was added, and the hydrolysates were cultured for $2 \mathrm{~h}$ at $37{ }^{\circ} \mathrm{C}$ in a $5 \%$ $\mathrm{CO}_{2}$ incubator and measured at $450 \mathrm{~nm}$ using an ELISA reader. Each treatment group underwent the experimental treatment three times, and the cell proliferation effect on the hydrolysates was represented as a percentage.

To determine the cell growth rate, MG-63 cells were plated on a $100-\mathrm{mm}$ dish at a cell number of $1 \times 10^{6}$ cells/mL, and hDPC was plated on a $100-\mathrm{mm}$ dish at a cell number of $1 \times 10^{5}$ cells $/ \mathrm{mL}$. The $L$. plantarum protein hydrolysates were reacted with tryphan blue solution at 1:1, and the unstained live cells were counted every other day for 10 days and observed at $\times 20$ magnification using an inverted microscope.

\section{Measurement of growth factor}

The vascular endothelial growth factor (VEGF) and insulin-like growth factor 1(IGF-1) concentrations were measured using the ELISA Kit ( $R$ \& D Systems, Minneapolis, MN, USA). Fifty microliters of assay diluent was added to $200 \mu \mathrm{L}$ of standard and culture samples, reacted at $37^{\circ} \mathrm{C}$ for $2 \mathrm{~h}$, and then washed three times. After that, $200 \mu \mathrm{L}$ of conjugate was added and reacted at $37^{\circ} \mathrm{C}$ for $2 \mathrm{~h}$ again. After washing three times, $200 \mu \mathrm{L}$ of substrate solution was added and reacted at $37^{\circ} \mathrm{C}$ for 20 $\min$. Then, $50 \mu \mathrm{L}$ of stop solution was added to stop the reaction. The absorbance was measured three times, and the absorbance value was calculated by subtracting the.

\section{Experimental animals}

Five-week-old C57BL/6 male mice were purchased from Samtako Bio Korea (O-San, Korea). The animals were allowed to eat food and drink water freely at a temperature of $24{ }^{\circ} \mathrm{C} \pm 0.5^{\circ} \mathrm{C}$, a humidity of $55-65 \%$, and $12 \mathrm{~h}$ of light cycle. They were used for the experiment after a 7-day period of adaptation.

\section{Application of the sample}

To apply the resting period during the circulation period of the hair, the back hair was first removed using an electric razor, and then the remaining hair was removed using a depilatory (Niclean, Ildong Pharmaceutical). There was no damage to the skin during hair removal, and continuous observation showed no inflammation. For each group, $100 \mu \mathrm{L}$ of each extract and 5\% minoxidil (Hyundai Pharm. Co., Korea) were applied to the backs whose hair had been removed twice a day (at 10:00 a.m. and 6:00 p.m.) for 14 days. Distilled water was used as a control.

\section{Visual observation of hair growth}

To verify the hair growth with the naked eye at $0,4,7$, 10, and 14 days after the start of the experiment, Zoletil (Virbac, Paris, France) and Rumpun (Bayel Korea Co. Seoul, Korea) were mixed at 9:1, and the mice were anesthetized $(10 / 10 \mathrm{~g})$ by intraperitoneal injection and then photographed. The hair growth of each group was rated by visual observation as $0-9 \%$ ( 0 points), $10-19 \%$ (1 point), $20-29 \%$ ( 2 points), 30-39 (3 points), 40-49\% (4 points), $50-59 \%$ (5 points), $60-69 \%$ (6 points), 70 $79 \%$ (7 points), $80-89 \%$ (8 points), and $90-100 \%$ (9 points). On the 14th day of the experiment, the mice were killed by cervical dislocation, the dorsal tissues were removed, and the inside of the extracted skin was visually observed.

\section{Statistical processing}

All experimental results are expressed as means and standard deviations. A one-way ANOVA was conducted for the resulting data using SPSS 20 (SPSS Inc., Chicago, IL, USA), and the data were tested with Duncan's multiple test at $p<0.05$.

\section{Conclusions}

The L. plantarum protein hydrolyzed with Protamex promoted hair growth more than did the $5 \%$ minoxidil. Minoxidil, which was developed as a hypertension treatment, is currently the best hair growth drug applied to the scalp. However, if used for more than 1 month, it 
causes side effects such as skin itching and erythema, as well as systemic side effects, such as a decrease in blood pressure. Thus, minoxidil is difficult to use for a long period. However, the hydrolysates of lactic acid bacteria proposed in this study demonstrated superior effects to $5 \%$ minoxidil without these side effects through hair growth experiments using C57BL/6 male mice. These results suggest that L. plantarum and its hydrolysates can be used as basic materials for the production of cosmetic ingredients, health foods, and medicines for growth, osteoporosis, etc.

\section{Abbreviations \\ bFGF: Basic fibroblast growth factor; IGF-1: Insulin-like growth factor 1; LP: Lactobacillus plantarum; LP-A: Lactobacillus plantarum by Alcalase; LP- B: Lactobacillus plantarum by bromelain; LP-P: Lactobacillus plantarum by Protamex; TGF- $\beta$ : Transforming growth factor- $\beta$; VEGF: Vascular endothelial growth factor}

\section{Acknowledgements}

This work was supported by the Technology Innovation Program (10,077,377, Development of hair and anti-aging cosmetic materials using lactic acid bacteria enzyme hydrolysates) funded By the Ministry of Trade, Industry \& Energy (MOTIE, Korea) and supported by the Brain Busan 21+ project (BB21+).

\section{Funding}

Not applicable.

\section{Authors' contributions}

YW, OK, EJ, and MJ carried out the experiments. YW, MA, YL, and $C L$ drafted the manuscript. SL, JC, JH, and AK guided the research and modified the manuscript. All authors read and approved the final manuscript.

\section{Competing interests}

The authors declare that they have no competing interests.

\section{Publisher's Note}

Springer Nature remains neutral with regard to jurisdictional claims in published maps and institutional affiliations.

\section{Author details \\ 'Major in Pharmaceutical Engineering, Division of Bioindustry, College of Medical and Life Sciences, Silla University, 140 Baegyang-daero(Blvd), 700beon-gil(Rd.), Sasang-Gu, Busan 46958, South Korea. ${ }^{2}$ Department of Natural Science Institute, Silla University, Busan 46958, South Korea. ${ }^{3}$ Protein Structure Group, Korea Basic Science Institute, Chungcheongbuk-do 28119, South Korea. ${ }^{4}$ Department of Food Engineering, Silla University, Busan 46958 , South Korea. ${ }^{5}$ School of Acu-moxibustion and Tuina, Liaoning University of Traditional Chinese Medicine, Shenyang 110847, China.}

Received: 14 December 2018 Accepted: 5 April 2019

Published online: 18 April 2019

\section{References}

Axling U, Olsson C, XU J, et al. Green tea powder and lactobacillus plantarum affect gut microbiota, lipid metabolism and inflammation in high-fat fed C57BL/6 mice. Nutr Metab. 2012;9:105.

Back SH, Yoon JB, Sim WY, Haw CR. Effects of vaseular endothelial growth factors on hair growth in vitro. Korean J Dermatol. 1999:37:23-30.

Buhl AE, Waldon DJ, Baker CA, Johnson GA. Minoxidil sulfate is the active metabolite that stimulates hair follicles. J Invest Dermatol. 1990;95:553-7.

Chang WK, Cho SB, Kim DW, Lee SS, Kim SK. Cell growth and antioxidant activity on onion juice fermentation by using lactobacillus plantarum as animal probiotics. J Life Sci. 2010;20:1729-37.

Choi HM, Hwang SJ, Lee JS, et al. Effects of hair tonic and food including Korean medicinal herbs on hair growth in an alopecia model of C57BL/6 mice. Kor J Herbology. 2011;26:119-24.
Choi SY, Kim SK, Youn UY, et al. Antimicrobial and ACE inhibitor activities of citrus unshiu fermented with lactic acid bacteria. J Korean Soc Food Sci Nutr. 2015;44:1084-9.

Choi WS, Kwon HS, Kim HW, No RW, Lee HY. Whitening effects of lactobacillus plantarum rhamnosus associated with its antioxidative activities. Korean J Microbiol Biotechnol. 2013:41:183-9.

Deckers MML, Karperien M, van der Bent C, et al. Expression of vascular endothelial growth factors and their receptors during osteoblast differentiation. Endocrinology. 2000;141:1667-74.

Do E, Hwang M, Kim SY, Lee J, Yang DS, Yang CH, Kim MR. The effect of Gyungokgo-gamibang extract on hair growth and protein expression in mice. Kor J Herbology. 2011;26:9-14.

Foitzik K, Spexard T, Nakamura M, Halsner U, Paus R. Towards dissectiong the pathogenesis of retinoid-induced hair loss: all-trans retinoic acid induces premature hair follicle regression (catagen) by upregulation of transforming growth factor- $\beta 2$ in the dermal papilla. J Invest Dermatol. 2005;124:1119-26.

Goad DL, Rubin J, Wang H, Tashiian AH, Patterson C. Enhanced expression of vascular endothelial growth factor in human SaOS-2 osteoblast-like cells and murine osteoblasts induced by insulin-like growth factor I. Endocrinology. 1996;137:2262-8

Ha WH, Park DH. Effect of seaweed extract on hair growth promotion in experimental study of C57BL/6 mice. Arch Craniofac Surg. 2013;14:1-10.

Hibino T, Nishiyama T. Role of TGF- $\beta 2$ in the human hair cycle. J Dermatol Sci. 2004;35:9-18.

Hwang HS, Hwang TH, Pyo AJ, Ju EH. Anti-oxidant efficacy and effects on expression of growth factors in human hair follicle dermal papilla cells of Rosa multiflora root extracts. Asian J Beauty Cosmetol. 2017;15:146-58.

Hyung SH, Gang SR, Kim YC. Effect of complex oriental medicine extract on hair growth promotion in an alopecia model of C57BL/6 mice. J Kor Soc Cosm. 2007:13:1366-75

Jamora C, Lee P, Kocieniewski P, Azhar M, Hosokawa R, Chai Y, Fuchs E. A signaling pathway involving TGF- $\beta 2$ and snail in hair follicle morphogenesis. PLoS Biol. 2005;3:131-43.

Jeon HY, Kim SH, Kim CW, et al. Korean J Food Sci Technol. 2011:43:747-53.

Joo SS. In vitro and in vivo hair growth promotion effects of lactobacillus plantarumfermented plant extracts (MBN). Korean J Food Sci Technol. 2011:43:381-6.

Kang MS, Oh HJ, Lee HC, Oh JS. Isolation and identification of lactic acid bacteria inhibiting the proliferation of propionibacterium acnes and Staphylococcus epidermidis. J Bacteriol Virol. 2009;39:11-9.

Kim KS. Research trends relevant with hair growth promotion and scalp condition improvement by applying natural extracts. Kor J Aesthet Cosmetol. 2014:12:17-24

Kwon OS, Han JH, Yoo HG, Chung JH, Cho KH, Eun HC, Kim KH. Human hair growth enhancement in vitro by green tea epigallocatechin-3-gallate (EGCG). Phytomedicine. 2007:14:551-5.

Lee HL, Lee JJ, Chang HC, Lee MY. Acute toxicity of lactobacillus plantarum AF1 isolated from kimchi in mice. Korean J Food Preserv. 2012:19:315-21.

Madaan A, Joshi V, Kishore A, Verma R, Singh AT, Jaggi M, Sung YK. In vitro hair growth promoting effects of naringenin and hesperetin on human dermal papilla cells and keratinocytes. Am J Dermatol Benereol. 2017;6:51-7.

Messenger AG, Rundegren J. Minoxidil: mechanisms of action on hair growth. $\mathrm{Br}$ J Dermatol. 2004;150:186-94.

Miele C, Rochford JJ, Filippa N, Giorgetti-Peraldi S, Obberghe EV. Insulin and insulin-like growth factor- I induce vascular endothelial growth factor mRNA expression via different signaling pathways. J Biol Chem. 2000; 275:21695-702.

Mitsul S, Ohuchi A, Hotta M, Tsuboi R, Ogawa H. Genes for a range of growth factors and cyclin-dependent kinase inhibitors are expressed by isolated human hair follicles. Br J Dermatol. 1997:137:693-8.

Olsen EA, Dunlap FE, Funicella T, et al. A randomized clinical trial of 5\% topical minoxidil versus $2 \%$ topical minoxidil and placebo in the treatment of androgenetic alopecia in men. J Am Acad Dermatol. 2002:47:377-85.

Park YM, Han JS. A study on the utilization of Dendropanax morbifera lev. Leaf extract for material of functional cosmetics and hair growth products. Asian J Beauty Cosmetol. 2016;14:277-88.

Philpott MP, Sanders DA, Kealey T. Effects of insulin and insulin-like growth factors on cultured human hair follicles: IGF- I at physiologic concentrations is an important regulator of hair follicle growth in vitro. $J$ Invest Dermatol. 1994;102:857-61.

Shapiro J. Price VH. Hair regrowth therapeutic agents. Dermatol Clin. 1998:16: $341-56$. 
Suh JD, Myung H, Kang N, Choung PH. The effects of insulin-like growth factor I (IGF- I) on expression of vascular endothelial growth factor (VEGF) mRNA in MG-63 osteoblastlike cells. J Kor Oral Maxilofac Surg. 2005;31:363-9.

Yeh LC, Lee JC. Osteogenic protein-1 increases gene expression of vascular endothelial growth factor in primary cultures of fetal rat calvaria cells. Mol Cell Endocrinol. 1999;153:113-24.

Submit your manuscript to a SpringerOpen ${ }^{\mathcal{O}}$ journal and benefit from:

- Convenient online submission

- Rigorous peer review

- Open access: articles freely available online

- High visibility within the field

- Retaining the copyright to your article

Submit your next manuscript at $\boldsymbol{\wedge}$ springeropen.com 